\title{
OSIL
}

\section{Larger cell or colony size in winter, smaller in summer - a pattern shared by many species of Lake Kinneret phytoplankton}

\section{Tamar Zohary, Tatiana Fishbein, Miriam Shlichter \& Luigi Naselli-Flores}

To cite this article: Tamar Zohary, Tatiana Fishbein, Miriam Shlichter \& Luigi Naselli-Flores (2017) Larger cell or colony size in winter, smaller in summer - a pattern shared by many species of Lake Kinneret phytoplankton, Inland Waters, 7:2, 200-209

To link to this article: http://dx.doi.org/10.1080/20442041.2017.1320505

\section{Published online: 20 Jun 2017.}

Submit your article to this journal $\sqsubset$

山 Article views: 13

Q View related articles $\square$

View Crossmark data 〔 


\title{
Larger cell or colony size in winter, smaller in summer - a pattern shared by many species of Lake Kinneret phytoplankton
}

\author{
Tamar Zohary, ${ }^{\text {a }}$ Tatiana Fishbein, ${ }^{a}$ Miriam Shlichter, ${ }^{a}$ and Luigi Naselli-Flores ${ }^{b}$ \\ aKinneret Limnological Laboratory, Israel Oceanographic and Limnological Research, Migdal, Israel; bepartment of Biological, Chemical and \\ Pharmaceutical Sciences and Technologies (STEBICEF) - Section of Botany and Plant Ecology, University of Palermo, Palermo, Italy
}

\begin{abstract}
We examined an 8.5-year record (2004-2012) of cell size data for phytoplankton species from Lake Kinneret, Israel, sampled weekly or at 2-week intervals and determined microscopically by the same person. Many of the species abundant enough to be counted year-round showed a typical seasonal cell size pattern that repeated annually: cell diameter was maximal in winter and minimal in summer. This pattern was shared by species from different taxonomic groups including cyanobacteria, chlorophyta, and dinoflagellates. Similarly, in colonial species of diatoms, chlorophyta, and cyanobacteria the number of cells per colony was larger in winter and smaller in summer. We postulated that the seasonal changes in cell or colony size constituted an adaptation that enabled species to overcome temperature-dependent changes in water density and viscosity and adjust their sinking velocities in the different seasons. A series of computations based on Stokes law supported our hypothesis. If this phenomenon of larger cells or colonies of the same species at lower temperatures is widespread in lake phytoplankton, then (1) phytoplankton biomass estimates should be based on seasonally determined biovolume per species data rather than fixed values; and (2) we would expect to see smaller-sized organisms in the future as global warming changes ambient temperatures.
\end{abstract}

\section{KEYWORDS}

chlorophyta; cyanobacteria; dinoflagellates; Reynolds number; sinking velocity; seasonal, Stokes' equation; temperature

\section{Introduction}

In his famous book "On Growth and Form," Sir D’Arcy Wentworth Thompson (Thompson 1917) was the first, now a century ago, to address issues associated with body size. He distinguished between smaller organisms, for which physical (mostly viscous) forces act mainly on their surface, and bigger organisms, for which the forces (mostly inertial) act proportionally on their body mass. For organisms living in moving fluids, the distinction between "small" and "big" can be expressed by the dimensionless Reynolds number $(R e)$, given as the ratio between the inertial and viscous forces acting on an object (Reynolds 1883). High Reynolds numbers $(R e>1)$ are typical of inertial forces with turbulent flow being dominant; low numbers $(R e<1)$ are typical of viscous forces with laminar flow being dominant. Thompson's work paved the road to studies on the adaptive value of size and shape in unicellular organisms living at $R e<1$. These studies were reviewed by Edward F. Adolph (1931) in his book, "The Regulation of Size as Illustrated in Unicellular Organisms," which summarized the available knowledge on the implication of size for metabolism and growth of microscopic organisms, including algae.

The literature that followed Adolph (1931) on the role of size in phytoplankton ecology focused initially on aspects other than physics. Lewis (1976) was the first to note the ecological role of size variability in phytoplankton in relation to uptake of light and nutrients and, as a result, the implications for natural selection and competition. Chisholm (1992) further emphasized the importance of size, stating that, "All aspects of the life of a phytoplankton cell are influenced, more or less, by its size." Trophodynamic studies on phytoplankton made it necessary to estimate phytoplankton biomass, which required the estimation of biovolume for each species encountered. The establishment of methods for biovolume determination in phytoplankton (Smayda 1978; Hillebrand et al. 1999) initiated the research on size variability. Margalef (1978) suggested that morphological variability in phytoplankton has a role in adaptation to different environmental templates. More recently, (Reynolds 1997, 2006 and literature therein) explained in detail how phytoplankton

CONTACT Tamar Zohary tamarz@ocean.org.il

${ }^{\S}$ Current address: Kinneret Limnological Laboratory, Israel Oceanographic and Limnological Research, Migdal, Israel.

(c) 2017 International Society of Limnology (SIL) 
size reflects the different environmental templates and formalized the adaptive role of phytoplankton size spectrum.

Size and morphology of phytoplankton are today recognized as important traits, explaining ecological functions and patterns such as those related to growth, abundance, reproduction, resource (nutrients and light) acquisition, predator avoidance, and even diversity (Finkel 2007; Litchman and Klausmeier 2008). According to Reynolds et al. (2002), algae belonging to the same functional group (i.e., those sharing similar ecological preferences) also have similar morphologies. Those morphologies, as quantified by the dimensions of the "algal units" (cells or colonies, as appropriate, together with any peripheral mucilage) are powerful predictors of phytoplankton optimum dynamic performance. Consequently, trait-based approaches, which include morphological analyses of the species involved, are increasingly used in phytoplankton ecology to explain and predict species distributions along environmental gradients (review by Salmaso et al. 2015). Several studies on the selective role exerted by environmental constraints on the phytoplankton morphological groups were obtained by categorizing species sharing similar dimensional and morphological traits (e.g., Naselli-Flores and Barone 2000; Naselli-Flores et al. 2007; Naselli-Flores 2014; Weithoff and Gaedke 2017 and literature therein). These studies, however, are generally performed at a community level (i.e., by assigning average values to phytoplankton size descriptors such as surface area, volume, maximum length, or surface to volume ratio) and by analysing the dynamics of the different phytoplankton functional groups in relation to the characteristics of the corresponding environmental template. None of these studies addressed the issues of morphological adaptions to environmental conditions at the species level.

Under changing environmental conditions (e.g., those occurring seasonally when stratification and circulation occur or, in a noncyclic way, under on-going eutrophication or acidification), a phytoplankton population, before being replaced by a more fitting population of a different species composition, may revert to its phenotypic plasticity to counteract the environmental changes. As suggested by Naselli-Flores and Barone (2000), environmental constraints may have a selective effect within the size range of single species. As an example, in a lake dominated by Closterium aciculare T West, a decrease in light availability will first select the longest cells (with a higher coefficient of form resistance and thus with a slower sinking velocity) already present in the population of $C$. aciculare before causing their replacement by another species better adapted to darker conditions. Moreover, size is related to sinking velocity (Padisák et al. 2003) and consequently influences the degree of entrainment

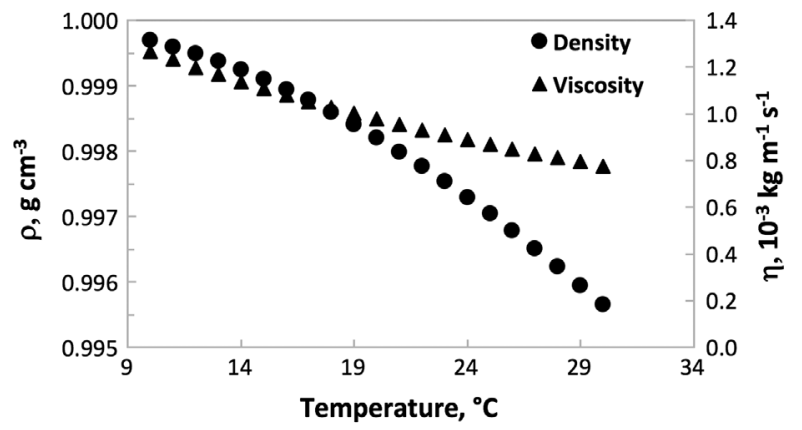

Figure 1. Changes of water density $(\rho)$ and water viscosity ( $\eta$ ) with temperature over the range of temperatures relevant to Mediterranean lakes.

of phytoplankton cells and colonies in water motion (Reynolds 2006). Therefore, many of the adaptations required by phytoplankton for regulating their life in a moving fluid would be expressed by size changes (NaselliFlores and Barone 2011).

Phytoplankton show a relatively wide spectrum of dimensions: 4 orders of magnitude separate between the length of picophytoplankton $(0.2-2 \mu \mathrm{m})$ and that of microphytoplankton $(20-200 \mu \mathrm{m})$. All these size classes show $R e<1$ and are therefore subjected to viscous forces, meaning that phytoplankton species evolved and are adapted to life in a physical world ruled by viscosity (i.e., by the drag exerted on the cell surface by water molecules; Vogel 1994). Viscosity affects phytoplankton cells or colonies through its impact on their sinking velocity; the higher the viscosity, the lower the sinking velocity. For microorganisms living at low Reynolds numbers, sinking velocity can be computed according to Stokes' law (Equation 1). According to the equation, the sinking velocity of a spherical particle in an aqueous medium is directly related to its radius squared and to its "excess density" (i.e., the difference between the density of the sinking particle and that of the water) and inversely related to the absolute viscosity of water. Both water density and its absolute viscosity are temperature dependent: they decrease with increasing temperatures (Fig. 1). Notably, at temperatures above $20{ }^{\circ} \mathrm{C}$, water density declines with increasing temperatures faster than does water viscosity (Fig. 1). The theory therefore postulates that, to maintain the same sinking velocity in the different seasons, phytoplankton cells must decrease their size in summer when water density is lower due to higher temperatures. This need to decrease size is further sustained by the steeper decrease in water density compared to the decline in absolute viscosity (Fig. 1).

To our knowledge, within-species size variability has never been investigated in natural populations of phytoplankton over extended periods that allow the elucidation of recurring seasonal patterns. The Lake Kinneret phytoplankton has been monitored on a regular basis since 
1969 (Zohary et al. 2014), with the taxonomic information stored as a digital online catalog (http://kinneret. ocean.org.il/phyt_cat_listView.aspx) containing photographs and morphological descriptions as well as molecular barcode data (Kaplan-Levy et al. 2016). Starting in August 2004, cell-size data were collected for every species encountered on every sampling date. Concurrently, the number of cells per colony were recorded for colonial species. The same person conducted all microscope counts and size measurements. The resulting long-term cell-size record reported in this study enabled the examination of seasonal patterns in cell and colony size of a series of common species occurring in Lake Kinneret.

This research tested the hypotheses that (1) cell and colony size of many species of phytoplankton varies seasonally, and (2) lower temperatures correlate with larger phytoplankton cells/colonies. We then assessed the factors that could contribute to moulding morphological trait changes in phytoplankton populations on a seasonal basis. Such changes are key to better forecasting population and assemblage responses to global change and other anthropogenic-driven environmental impacts and to eventually improve ecosystem management planning.

\section{Methods}

Water samples for conducting phytoplankton cell counts and size measurements were collected weekly from 9 to 11 discrete depths at the deepest part of Lake Kinneret (Station A) from August 2004 until December 2012 and preserved in Lugol's solution. Sampling was part of a larger monitoring program for the lake and always took place between 0830 and $1030 \mathrm{~h}$. Cell and colony abundance of all species occurring in those samples were estimated by the inverted microscope method (Utermöhl 1931; Lund et al. 1958) as detailed by Zohary (2004). Cell size measurements for each species and sampling date were conducted on a single "mixed" sample for each sampling date, composed of $10 \mathrm{~mL}$ subsamples of the 9-11 discrete-depth samples. We placed $50 \mathrm{~mL}$ of the mix in a sedimentation chamber for at least $40 \mathrm{~h}$, after which the supernatant was discarded and the chamber floor examined with a Zeiss Axiovert M135 microscope equipped with a DFK-41BF02 digital camera and an iMac computer. For each mixed sample, 10 individuals of each species were measured, although occasionally the number of individuals of rare species measured was smaller. All size measurements were conducted by the same person (T. Fishbein) using PlanktoMetrix, a customized software package for counting and sizing plankton (Zohary et al. 2016). The larger species were counted and measured weekly and the smaller species every second week.
PlanktoMetrix computed biovolume per cell for each individual measured, using the equations of Hillebrand et al. (1999). All raw measurements and biovolume data were exported to an Access database for manipulations, using proprietary data viewing routines. Data presented here are means of the linear dimensions or of computed biovolumes of the 10 individual cells measured for each species on each sampling date. To examine seasonal patterns of cell size of individual species, only species abundant enough to be counted and measured at all or most times of the year over several years were included in the following analyses. Species that were absent from the water column for several months of the year were excluded.

For each species, the median of the 8 annual maxima and 8 annual minima (2005-2012) of cell or filament diameter and biovolume were computed. The ratio of the median of maxima to the median of minima (hereafter $\max / \mathrm{min}$ ), was used as proxy for the extent of size variability within each species. These median values were also used to calculate the radius of equivalent spheres for computing sinking velocity.

Sinking velocity was estimated for each species at $15^{\circ} \mathrm{C}$ (winter) and $30^{\circ} \mathrm{C}$ (summer) and considering the maximum winter and minimum summer values of the radius of the equivalent sphere, according to Stokes' equation:

$$
\mathrm{V}_{\mathrm{s}}=(2 / 9) g_{n} r^{2}\left(\rho^{\prime}-\rho\right)\left(\eta^{-1}\right)\left[\mu \mathrm{m} \mathrm{s}^{-1}\right],
$$

where $\mathrm{V}_{s}$ is the sinking velocity of a spherical particle (in $\left.\mu \mathrm{m} \mathrm{s}^{-1}\right), \mathrm{r}$ is its radius $(\mu \mathrm{m}), g_{n}$ is the standard gravity $\left(9.806 \times 10^{-6} \mathrm{~m} \mathrm{~s}^{-2}\right), \rho^{\prime}$ is the density of the sinking particle

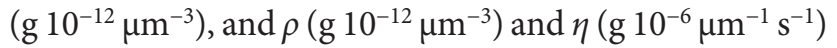
are, respectively, the density and the absolute viscosity at the given water temperatures. Water density and absolute viscosity were assumed to be those of pure water and computed using a fluid properties calculator available at http:// www.mhtl.uwaterloo.ca/old/onlinetools/airprop/airprop. html (last accessed 6 Oct 2016).

Phytoplankton cell density used in the computations is an estimate based on values available in the literature (Reynolds 1984, 2006). A value of $1.15 \mathrm{~g} \mathrm{~cm}^{-3}$ was used for dinoflagellates and $1.09 \mathrm{~g} \mathrm{~cm}^{-3}$ for chlorophytes. For cyanobacteria, a value of $0.985 \mathrm{~g} \mathrm{~cm}^{-3}$ was used for gas-vacuolated species and $1.09 \mathrm{~g} \mathrm{~cm}^{-3}$ for species without gas vesicles.

Net growth rates were computed from the weekly or fortnightly cell abundance data using the equation: $r=\ln \left(N_{1} / N_{0}\right) /\left(t_{1}-t_{0}\right)$, where $r\left(\mathrm{~d}^{-1}\right)$ is the net growth rate, and $N_{1}$ and $N_{0}$ are cells $\mathrm{mL}^{-1}$ at time $1\left(t_{1}\right)$ or time $0\left(t_{0}\right)$, respectively.

Additional data collected concurrently as part of the monitoring program on Lake Kinneret (Sukenik et al. 2014) were made available to this project. These data 

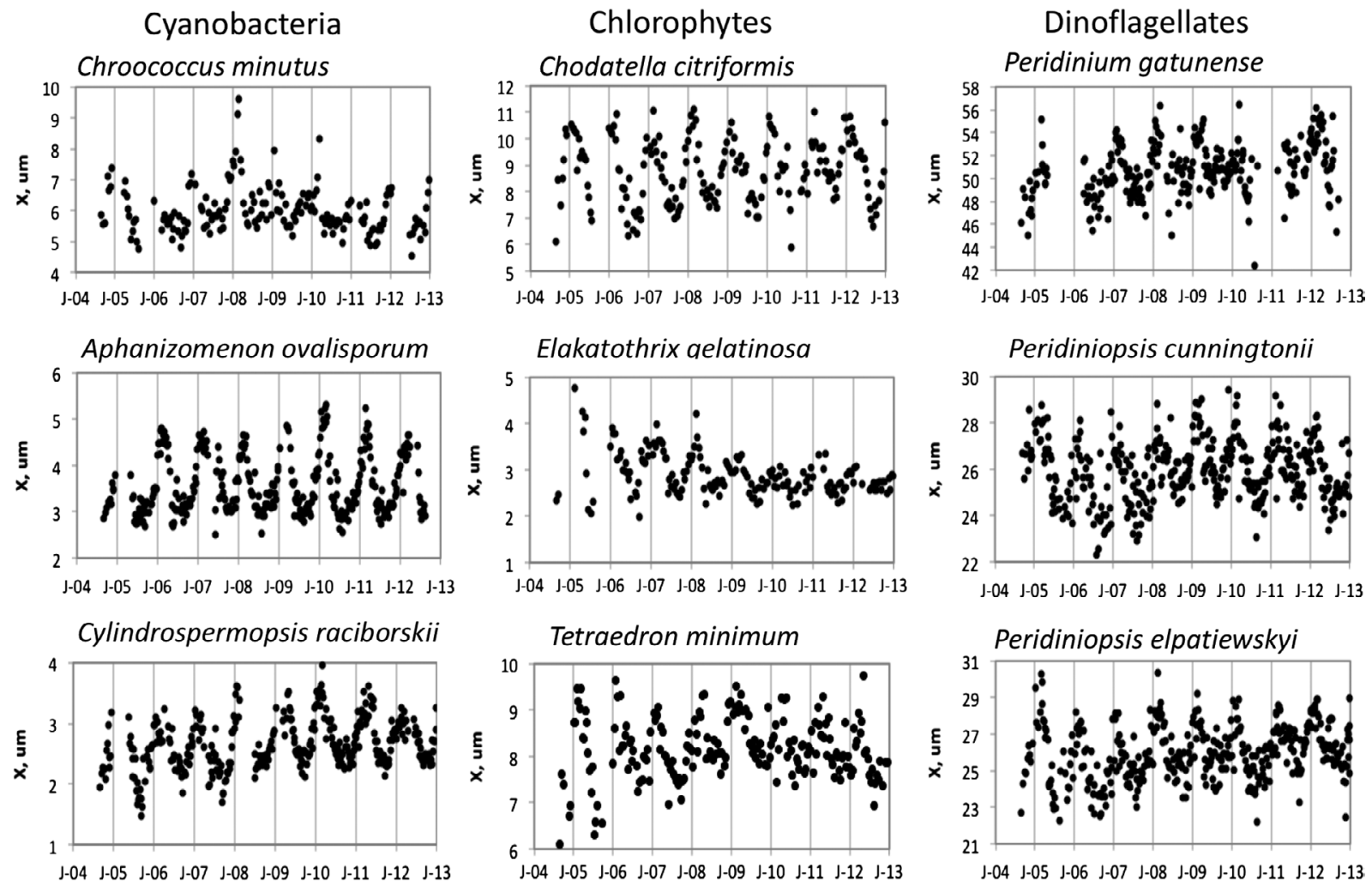

Figure 2. Time series (Aug 2004 to Dec 2012) of cell diameter in 9 species from Lake Kinneret (3 cyanobacteria, 3 chlorophytes, 3 dinoflagellates) demonstrating a typical, repeatable pattern: larger cell size in winter, smaller in summer. Vertical lines mark 1 January of each calendar year. Data points shown are means of 10 measurements for each species on each sampling date.

included variables such as mean $0-10 \mathrm{~m}$ water temperature, the depth of the euphotic zone $\left(z_{\text {eu }}\right)$, the depth of the mixed layer $\left(z_{\text {mix }}\right)$, Secchi depth, and nutrient concentrations (means of values determined on samples collected from $1,3,5$, and $10 \mathrm{~m}$ at each sampling time). The result was a comprehensive database containing, for each species, a time series of cell abundance, cell size, cells per colony, and net growth rate together with limnological data (temperature, light, and nutrients). Ordinary least squares regression analysis was conducted to examine the relationship between the listed environmental variables and cell size.

\section{Results}

\section{Seasonality of cell and colony size}

Of the 155 species currently occurring in Lake Kinneret (Zohary et al. 2014), 19 species were abundant enough to be measured throughout the year over several years. By examining the time series of cell-size data for this subset of species, a typical pattern emerged: cell diameter fluctuated seasonally, being maximal in winter and minimal in summer (Fig. 2). This pattern was shared by species from different taxonomic groups including cyanobacteria (e.g., Chroococcus minutus [Kutzing] Nägeli, Aphanizomenon ovalisporum Forti, and Cylindrospermopsis raciborskii Seenayya et Subba Raju); Chlorophytes (e.g., Lagerheimia [previously Chodatella] citriformis [JW Snow] Collins, Elakatothrix gelatinosa Wille, and Tetraedron minimum [A Braun] Hansgirg); and dinoflagellates (e.g., Peridinium gatunense Nygaard, Peridiniopsis cunningtonii Lemmerman, and Peridiniopsis elpatiewskyi [Ostenfeld] Bourrelly).

The extent of fluctuation in cell diameter varied among species, with a median maximum size (= median of 8 annual maxima) 1.1-1.7 times the median minimum size (Table 1). The largest fluctuations in cell diameter were found for the cyanobacterium Aphanizomenon ovalisporum and the smallest for the dinoflagellates Peridinium gatunense and Peridiniopsis cunningtonii. Cell or filament biovolume fluctuated accordingly, with the ratios of max/ min ranging between 1.4 and 1.6 for the dinoflagellates and 3.7 for the double-cone shaped chlorophyte Elakatothrix gelatinosa (Table 1).

Not only cell size but also colony size (as manifested in the number of cells per colony or filament) showed similar seasonality, with longer filaments or larger colonies in late winter and smaller ones in late summer (Fig. 3). Again, this phenomenon was shared by species from different taxonomic groups. For example, Cyanodictyon 
Table 1. Observed range of variability in maximum ( $\max$ ), minimum (min), and max/min cell or filament diameter, cell or filament biovolume, and sinking velocity for 3 cyanobacteria, 3 chlorophytes, and 3 dinoflagellates from Lake Kinneret. Max/min diameter and biovolume values reported are medians of the annual maximum and annual minimum values for each of the 8 years from 2005 to 2012. Sinking velocities were computed according to Stokes' law for an equivalent volume sphere using the respective maximum and minimum cell dimensions, and water temperature of $15^{\circ} \mathrm{C}$ in winter and $30^{\circ} \mathrm{C}$ in summer.

\begin{tabular}{|c|c|c|c|c|c|c|c|c|c|}
\hline \multirow[b]{2}{*}{ Species } & \multicolumn{3}{|c|}{ Cell or filament diameter $(\mu \mathrm{m})$} & \multicolumn{3}{|c|}{ Cell or filament biovolume $\left(\mu \mathrm{m}^{3}\right)$} & \multicolumn{3}{|c|}{ Sinking velocity $\left(\mu \mathrm{m} \mathrm{s}^{-1}\right)$} \\
\hline & $\max$ & $\min$ & $\max / \min$ & $\max$ & $\min$ & $\max / \min$ & $\max$ & $\min$ & $\max / \min$ \\
\hline Aphanizomenon ovalisporum & 4.7 & 2.8 & 1.7 & 3510 & 1293 & 2.7 & -2.5 & -1.4 & 1.8 \\
\hline Cylindrospermopsis raciborskii & 3.2 & 2.3 & 1.4 & 1709 & 492 & 3.5 & -1.5 & -0.7 & 2.1 \\
\hline Chroococcus minutus & 6.9 & 5.0 & 1.4 & 182 & 68 & 2.7 & 1.2 & 0.6 & 1.9 \\
\hline Elakatothrix gelatinosa & 3.6 & 2.3 & 1.6 & 60 & 16 & 3.7 & 1.0 & 0.6 & 1.6 \\
\hline Lagerhaeimia citriformis & 10.7 & 7.0 & 1.5 & 758 & 239 & 3.2 & 5.6 & 3.8 & 1.5 \\
\hline Tetraedron minimum & 9.3 & 7.5 & 1.2 & 426 & 215 & 2.0 & 5.6 & 3.6 & 1.6 \\
\hline Peridiniopsis cunningtonii & 28.1 & 24.5 & 1.1 & 14270 & 9953 & 1.4 & 67 & 53 & 1.3 \\
\hline Peridiniopsis elpatiewskyi & 28.2 & 23.9 & 1.2 & 14394 & 9040 & 1.6 & 68 & 50 & 1.4 \\
\hline Peridinium gatunense & 53.7 & 47.5 & 1.1 & 87262 & 61764 & 1.4 & 224 & 178 & 1.3 \\
\hline
\end{tabular}
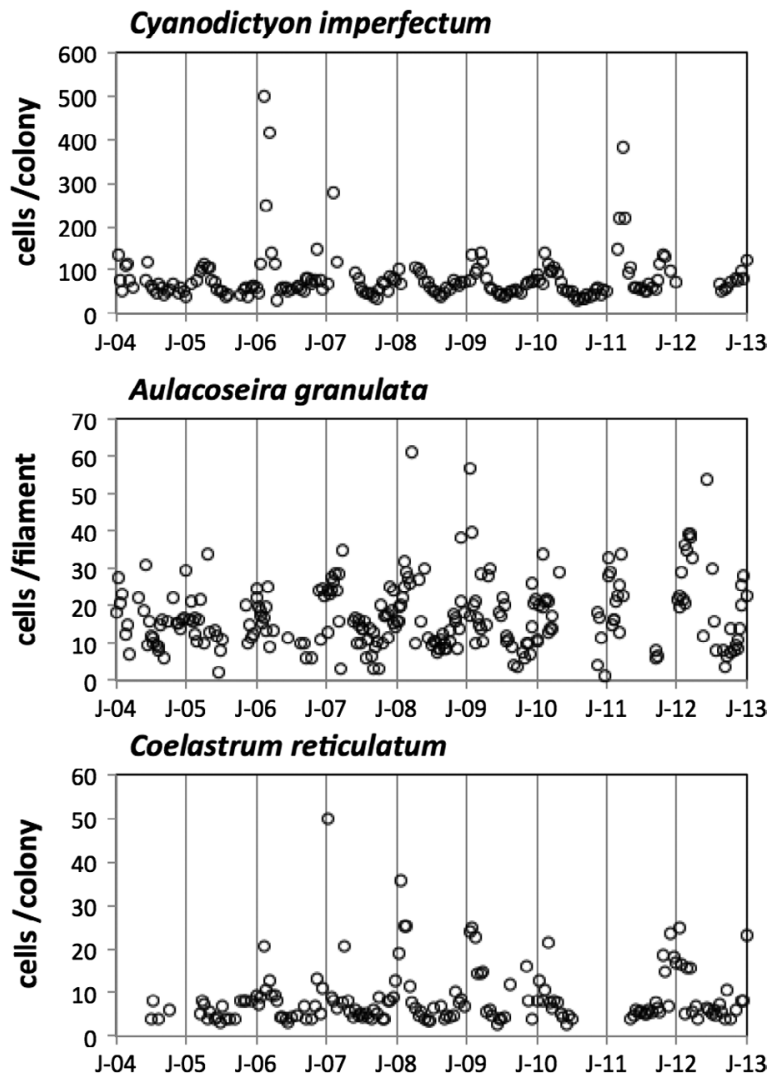

Figure 3. Temporal changes in the mean number of cells per colony of Cyanodictyon imperfectum (Cyanobacteria, Chroococales) or the mean number of cells per filament of Aulacoseira granulata (Bacillariophyta, Centrales) and Hariotina reticulata (Chlorophyta, Chlorococcales) during 2004-2012.Vertical linesindicate 1 January of each calendar year.

imperfectum Cronberg and Weibull (cyanobacteria) colonies fluctuated between compositions of $\sim 50$ cells in late summer to $\sim 150$ cells in late winter. Aulacoseira granulata (Ehrenberg) Simonsen (centric diatom) filaments were made of $<10$ cells in late summer but exceeded 25 cells in late winter. Hariotina (previously Coelastrum) reticulata PA Dangeard (chlorophyte) coenobia exceeded an average of 20 cells in winter but consisted mostly of 8 or less cells in summer.

\section{Cell size and biological and environmental parameters}

For most species, cell size or colony size was not significantly related to cell or colony abundance, biomass concentration, or growth rate (Table 2). For several species (e.g., Peridinium gatunense, Peridiniopsis elpatiewskyi, and Cylindrospermopsis raciborskii), peak abundance lagged several months behind peak cell size but preceded the minimum cell size. The same pattern was recorded for colony abundance and colony size of Hariotina reticulata. For other species, such as Elakatothrix gelatinosa, there was no evident relationship between cell/colony size and abundance or biomass. For Cyanodictyon imperfectum and Aphanizomenon ovalisporum, a negative relationship was found, with the smallest colonies usually occurring at the time of highest colony abundance and vice versa. Overall, there was no general pattern common to most cases examined. No significant correlation between cell size and net growth rate was found for any of the species examined (Table 2). Our data did not allow computing maximum growth rates.

During the study period, mean water temperature for the uppermost $10 \mathrm{~m}$ layer of Lake Kinneret ranged between winter minima of $14-16^{\circ} \mathrm{C}$ and summer maxima of $29-31{ }^{\circ} \mathrm{C}$. Ordinary least squares regression analyses showed significant inverse linear relationships between cell diameter and the mean $0-10 \mathrm{~m}$ water temperature for all species examined, with $R^{2}>0.3, p>0.01$ (Table 2). These correlations were strong in particular for Aphanizomenon ovalisporum (Fig. 4), Lagerheimia citriformis, and Elakatothrix gelatinosa, with $R^{2}>0.6$ (Table 2), uncommon for field data.

Other environmental parameters were also significantly correlated with cell size (Table 2). In particular, 
Table 2. $R^{2}$ values of simple linear regressions between cell diameter of the 9 species listed and a series of biological and environmental parameters; $n=$ number of cases. Biological parameters: biomass concentration, net growth rate $(r)$; physical parameters: $T=$ mean temperature of the upper 0-10 m layer, $z_{\text {mix }}=$ mixing depth, $z_{\text {mix }} / z_{\text {eu }}=$ ratio of mixing depth to euphotic depth; chemical parameters: $\mathrm{NH}_{4}, \mathrm{NO}_{3^{\prime}}$ TN, TDP, TP. With $n>80$ for all species, $R^{2}=0.29$ corresponds to $p=0.01 ; R^{2}=0.36$ corresponds to $p=0.001$, so all the bold $R^{2}$ values are highly significant.

\begin{tabular}{|c|c|c|c|c|c|c|c|c|c|c|c|}
\hline Species & $n$ & Biomass conc. & $r$ & $\mathrm{~T}$ & $z_{\text {mix }}$ & $z_{\mathrm{mix}} / z_{\mathrm{eu}}$ & $\mathrm{NH}_{4}$ & $\mathrm{NO}_{3}$ & TN & TDP & TP \\
\hline Chroocuccus minutus & 107 & 0.02 & 0.02 & 0.44 & 0.39 & 0.36 & 0.37 & 0.04 & 0.19 & 0.02 & 0.08 \\
\hline Aphanizomenon ovalisporum & 106 & 0.19 & 0.10 & 0.70 & 0.46 & 0.44 & 0.19 & 0.46 & 0.54 & 0.06 & 0.21 \\
\hline Cylindrospermopsis raciborskii & 83 & 0.01 & 0.07 & 0.46 & 0.12 & 0.09 & 0.13 & 0.35 & 0.27 & 0.10 & 0.10 \\
\hline Chodatella citriformis & 125 & 0.05 & 0.05 & 0.74 & 0.38 & 0.37 & 0.25 & 0.28 & 0.42 & 0.07 & 0.08 \\
\hline Elakatothrix gelatinosa & 100 & 0.00 & 0.03 & 0.61 & 0.28 & 0.33 & 0.14 & 0.14 & 0.40 & 0.02 & 0.20 \\
\hline Tetraedron minimum & 130 & 0.06 & 0.01 & 0.33 & 0.05 & 0.09 & 0.02 & 0.29 & 0.24 & 0.07 & 0.20 \\
\hline Peridiniopsis elpatiewskyi & 134 & 0.01 & 0.01 & 0.46 & 0.29 & 0.20 & 0.13 & 0.28 & 0.22 & 0.08 & 0.11 \\
\hline Peridinium gatunense & 94 & 0.04 & 0.04 & 0.34 & 0.24 & 0.21 & 0.12 & 0.14 & 0.18 & 0.05 & 0.16 \\
\hline
\end{tabular}
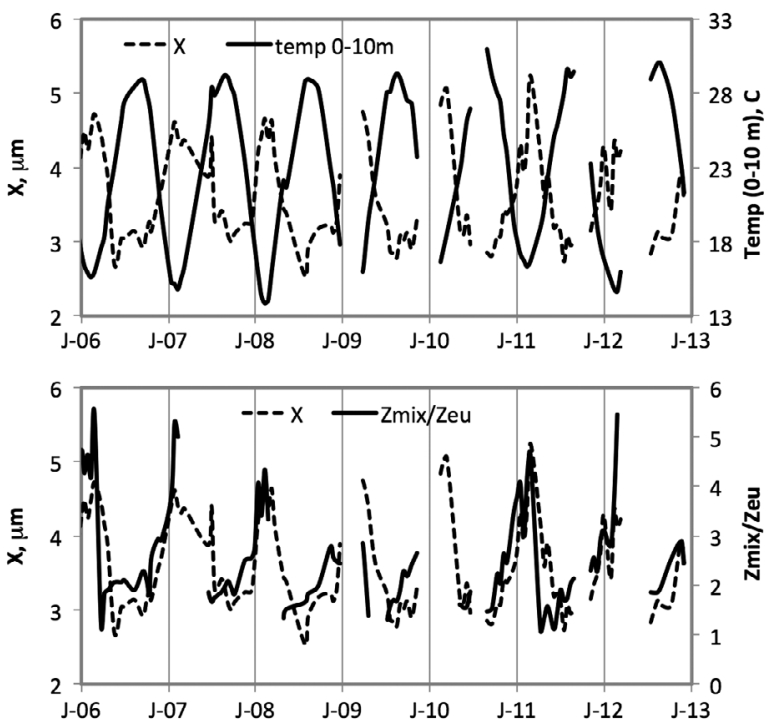

Figure 4. Time series of cell diameter ( $x, \mu \mathrm{m}$, dashed line) of Aphanizomenon ovalisporum in Lake Kinneret and (a) temperature of the upper $10 \mathrm{~m}$ layer (solid line, upper panel), showing a strong negative relationship or (b) $z_{\text {mix }} / z_{\text {eu }}$ (solid line, lower panel), showing a strong positive relationship. Vertical lines indicate 1 January of each calendar year.

mixing depth $z_{\text {mix }}$ the ratio of $z_{\text {mix }}$ to euphotic zone depth $z_{\text {mix }} / z_{\text {eu }}$, nitrate concentration, and total nitrogen (TN), showed strong positive correlations with cell size of Aphanizomenon ovalispsorum (Fig. 4) and several other species (Table 2). Of interest were the high and significant correlations found for the chlorophytes Lagerheimia citriformis and Elakatothrix gelatinosa with TN but not with the inorganic species of $\mathrm{N}$, suggesting that perhaps organic $\mathrm{N}$ plays a role. For the 2 filamentous cyanobacteria Aphanizomenon ovalisporum and Cylindrospermopsis raciborskii, filament length (indicative of the number of cells per filament) was not correlated with any of the nutrient species tested.

\section{Cell size and sinking velocity}

The increase in linear dimensions observed in winter had a direct effect on cell biovolumes and, consequently,

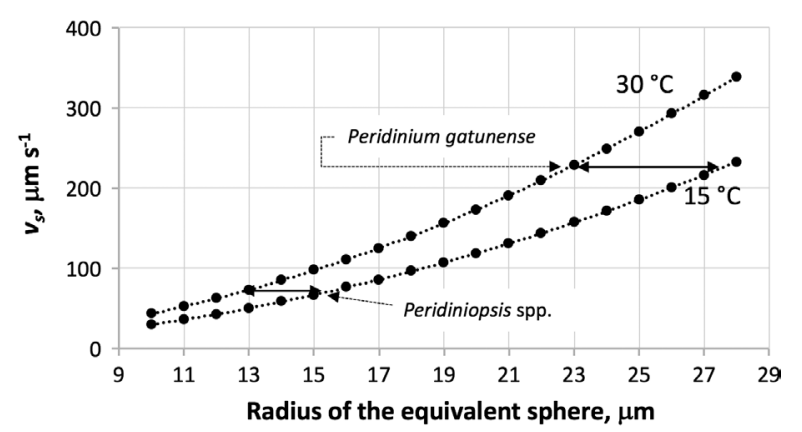

Figure 5. Theoretical trends of sinking velocities, $\left(\mathrm{V}_{s^{\prime}} \mu \mathrm{m} \mathrm{s} \mathrm{s}^{-1}\right)$ computed for $15{ }^{\circ} \mathrm{C}$ (winter temperature) and $30{ }^{\circ} \mathrm{C}$ (summer temperature) for spherical particles in the size range of Kinneret dinoflagellates. The horizontal solid arrows show how much the radius of a sphere of a size similar to that of Peridinium gatunense (upper) or Peridiniopsis spp. (lower) must increase in winter to achieve the same sinking velocity computed in summer. Calculations were performed as described in the methods.

on cell sinking velocity computed according to Stokes' equation. The level of increase was comparable within the same taxonomic group, although somewhat different between those groups (Table 1). In particular, in dinoflagellates winter sinking velocity was $1.3-1.4$ times faster than in summer. All the studied chlorophytes showed an increase in winter sinking velocity by a factor of 1.5-1.6 compared to summer sinking velocity, whereas for cyanobacteria, absolute sinking velocity in winter was between 1.8 (Aphanizomenon ovalisporum) and 2.1 (Cylindrospermopsis raciborskii) higher than in summer. This change in cyanobacteria sinking velocity was independent of their content of gas vesicles, and Chroococcus minutus (a cyanobacterium with no gas vesicles) showed a comparable winter increase (1.9) in its sinking velocity. The increase in the radius of the equivalent sphere from summer to winter observed in dinoflagellates, an increase of 23 to $27.5 \mu \mathrm{m}$ in Peridinium gatunense and of 13 to $15 \mu \mathrm{m}$ in Peridiniopsis spp., is sufficient to regulate the sinking velocity at values closely comparable to those calculated considering the size achieved in summer 
(Fig. 5). Conversely, the winter increase in biovolume observed in all the other algae is 3-4 times higher than that required by the Stokes' law to increase sinking to values comparable to summer values (data not shown).

\section{Discussion}

The availability of a long-term record of size measurements on all phytoplankton species occurring in Lake Kinneret made it possible to elucidate the existence of a distinct pattern of larger individuals of the same species in winter and smaller in summer, a pattern that repeated itself over 8 consecutive years. This pattern was common to a wide range of species from all the major freshwater taxonomic groups: cyanobacteria, chlorophytes, dinoflagellates, and diatoms. These species showed a great variety of morphological traits (e.g., large and small unicells, filamentous and spherical colonies, cells with and without mucilage, capable and incapable of independent motility), suggesting that the seasonally fluctuating cell/colony size could be a general feature of phytoplankton in lakes subjected to strong seasonal cycles. Our results call for a much wider-scale species-level examination of temporal dynamics of phytoplankton cell and colony size to establish whether the phenomenon observed in Lake Kinneret characterizes other lakes and aquatic systems. We hope that this line of investigation will stimulate interest and the further contributions of other plankton scientists. The software PlanktoMetrix (Zohary et al. 2016), a free tool, could be useful for collecting the needed long-term cell size data from different lakes in a standardized way. If seasonal fluctuations of within-species cell/colony size are wide-spread, an important implication for studies of phytoplankton temporal dynamics in lakes is that phytoplankton biomass estimates should be based on seasonally determined biovolume-per-individual data rather than on fixed values.

The obvious next step is to search for an explanation to the seasonal fluctuations of cell size. We propose that a likely explanation is the need for phytoplankton to remain entrained in water motions (e.g., in an environment where its sinking velocity depends on water viscosity and density) that change with water temperature. The rest of the discussion is focused on this explanation.

All phytoplankton organisms share a common characteristic: they are adapted to being suspended in water (Reynolds 1997, 2006). Living in suspension implies that the vital activities of phytoplankton, including all those directed toward optimizing resource acquisition, occur in a fluid that is constantly in motion. Adaptation to life in suspension in a dynamic fluid requires balancing between the necessity to maximize the exposure to adequate light and to sufficient nutrients (Zohary et al. 2010) while remaining entrained in a constantly moving fluid. Size, as described by surface to volume ratio, and shape have important roles in modulating nutrients and light uptake and in determining phytoplankton spatial distribution in the mixed layers (e.g., Reynolds 2006; Litchman and Klausmeier 2008; Naselli-Flores and Barone 2011). In a population or in an assemblage, different environmental templates will select for individuals/species that best fit the actual environmental constraints (Reynolds et al. 2002). Modifications to the size (which may occur in individuals belonging to the same species) or to the shape (most commonly achieved by changing species composition) can modify the degree of entrainment of phytoplankton in water motion. Entrainment depends on the ratio between the sinking velocity of the organism through the water and the turbulent velocity of water itself (Humphries and Imberger 1982).

Turbulent velocity is a feature of the water, over which phytoplankton has no control. According to Stokes' law, phytoplankton populations can regulate their entrainment in water motions by modifying their average size and/or their cellular density. As shown by Reynolds $(1997,2006)$, modifications in cellular density are unlikely to effectively affect sinking behavior of phytoplankton when compared to the effects due to morphological changes in cell or colony size. Conversely, a selective increase/decrease in the average size of a population can have a significant effect on sinking velocity and ultimately on phytoplankton entrainment. Shape is also of great importance because it influences the morphological resistance to sinking (Padisák et al. 2003); however, the effects of shape are speciesspecific and, in the majority of species, shape does not vary significantly. Hence, shape is relevant at a community level analysis but much less at a species level.

Life at low Reynolds numbers, as that experienced by phytoplankton, is ruled by water properties related to density and viscosity, inertia being negligible compared to drag (Vogel 1994: chapter 15). Water density and viscosity are the 2 physical variables affecting the sinking velocity (Equation 1) and ultimately the entrainment of phytoplankton in the moving fluid (Reynolds 2006). Based on their dependence on water temperature (Fig. 1), density and viscosity fluctuate seasonally in temperate and subtropical waterbodies. Temperature effects on phytoplankton resource acquisition and growth are well known (e.g., Elliott et al. 2006; Fanesi et al. 2016 and literature therein). To our knowledge, however, the effects of seasonal temperature fluctuations on entrainment and sinking are seldom considered in phytoplankton ecological studies, and only few studies were found on seasonal variation of phytoplankton morphology (Bailey-Watts and Kirika 1981; De Miranda et al. 2005; Jung et al. 2013). Recent studies relating phytoplankton behavior and morphology 
to climate change (e.g., Paerl and Huisman 2008; De Senerpont Domis et al. 2013; Rasconi et al. 2015) mostly focus on "external" drivers of change (e.g., increased runoff and nutrient loading, stratification patterns, food web alterations), without considering the effects on phytoplankton morphology exerted by the seasonal changes in water density and viscosity. External factors, although undoubtedly important, do not fully explain the morphological variability observed in phytoplankton species. The majority of studies on phytoplankton are focused on a "community" perspective. Our unique dataset from Lake Kinneret enabled us to take a different view and focus on the individual species.

Wind speed over Lake Kinneret, and the consequent hydrodynamic habitat, show a marked seasonality; Mediterranean Sea breeze (westerly winds) dominates in summer with speeds ranging between 2 and $10 \mathrm{~m} \mathrm{~s}^{-1}$, maintaining a well-mixed epilimnion, whereas in winter weak winds predominate $\left(\sim 1 \mathrm{~m} \mathrm{~s}^{-1}\right)$ with no dominant direction (Imberger and Marti 2014; Ziv et al. 2014). In this range of wind speeds, vertical movements of the investigated phytoplankton species are dominated by turbulent mixing (Reynolds 1997) throughout the year. Although phytoplankton are deeply embedded within the turbulent structure of water, entrainment is not infinite, and eventually most phytoplankton will sink to the bottom of the waterbody (Reynolds 2006). The dynamic physical world in which phytoplankton live exerts pressures on their morphological characteristics (size and shape), selecting individuals that can ensure the best possible position with regard to resource acquisition in the moving water layers.

In Lake Kinneret, significant correlations were found between cell size of all the studied species and water temperature. Mixing depth to euphotic depth ratio and nitrogen nutrients were also correlated to cell size, an expected finding because those environmental parameters also fluctuate seasonally. Water temperature follows air temperature (i.e., coldest in late winter, warmest in late summer). The $z_{\text {mix }} / z_{\text {eu }}$ ratio is highly dependent on average $z_{\text {mix }}$, which fluctuates between the lake average depth $(\sim 25 \mathrm{~m})$ during winter holomixis and the depth of the thermocline $(\sim 15 \mathrm{~m})$ during summer stratification, whereas the seasonal fluctuations of light penetration and euphotic zone depth are marginal (Yacobi et al. 2014). Ambient nutrient concentrations also peak in winter and decline to low background levels in summer (Berman et al. 2014) because their 2 major sources are turnover (in Dec or Jan) and inflows (that depend on winter floods; Rom et al. 2014). According to the nutrient trends, and in agreement with C-S-R- strategy theory, larger organisms with lower surface area to volume ratios should be considered more acquisitive, best fitting a decreased nutrient availability (Naselli-Flores 2014). It is therefore unlikely that the larger size of phytoplankton in winter was due to increased nutrient availability.

Grazers are also known to have an impact on the size structure of phytoplankton populations (Reynolds 2012; Acevedo-Trejos et al. 2015). Bailey-Watts (1986) showed that dense swarms of crustacean zooplankton heavily impacted the length spectra of filamentous species (e.g., Planktothrix, Aulacoseira). Bergquist et al. (1985) reported on shifts in phytoplankton size structure and community composition in response to grazers. We considered zooplankton grazing to play a minor role in shaping the seasonal pattern of cell/colony size of the different species in Lake Kinneret, however, because the same seasonal pattern was shared by both edible and non-edible species. Hence, potential zooplankton impacts were considered beyond the scope of this article.

Larger organisms tend to sink faster, but this effect can be compensated by an increased form resistance to sinking. Padisák et al. (2003) showed that, in filamentous organisms, an increased ratio between length and diameter decreases sinking velocity (i.e., at a fixed length, thinner filaments sink slower than thicker ones). An analogous effect can be achieved by increasing the cell length (Naselli-Flores and Barone 2007) or the number of cells of the same diameter in a filament, as observed in the present study for Aulacoseira granulata in winter. Thus, considering that Aphanizomenon ovalisporum and Cylindrospermopsis raciborskii from Lake Kinneret showed thicker filaments in winter, a contrasting strategy seems to occur in cyanobacteria and diatoms, probably because gas vesicles in cyanobacteria offer a further possibility to regulate the position of the organisms in the water column compared to diatoms. Actually, an increase in cell dimensions could provide a dilution of the gas vesicle content in the cell body and a consequent increase in sinking velocity.

Calculating sinking velocity of phytoplankton using Stokes' equation does not account for all the so called "vital factors" that cause sinking rates of living organisms to deviate from the computed values (Naselli-Flores and Barone 2011). This phenomenon is also shown in our results. Highly motile dinoflagellates showed the lowest increase in sinking velocity with declining temperature, probably because they can modify their position in the water column by active swimming; cyanobacteria had to counteract buoyancy imparted by gas vesicles and showed the highest increase. Non-motile chlorophytes showed increments of $\sim \times 1.7$, comparable to that observed in the deepening of the mixing depth that occurs in Lake Kinneret from $25 \mathrm{~m}$ (mean depth) during lake holomixis in winter to $15 \mathrm{~m}$ (thermocline depth) during summer stratification.

Furthermore, we could estimate that the increase in cell dimension is sufficient to maintain a winter sinking velocity similar to that achieved in summer by dinoflagellates; 
however, cyanobacteria and chlorophytes had winter dimensions much larger than those expected by computing sinking velocity. Again, for cyanobacteria the larger than expected change in dimensions can be explained by the presence of the gas vesicles, whereas other factors (e.g., presence of mucilage and/or extended perturbations) could be responsible for dimensional increase in chlorophytes.

We therefore suggest that, in the case of Lake Kinneret, seasonal changes in cell size are governed mostly by the need to regulate sinking velocities. Temperature is a surrogate for density, and colder waters are denser and more viscous. Phytoplankton sinking rates in denser water are slower. Smaller cells sink slower than larger cells, hence large cells thrive better in winter but would sink fast in summer and disappear from the water column. Our findings from Lake Kinneret fall within the framework of Bergmann's rule (based on Bergmann 1847), which states that within a broadly distributed taxonomic clade, populations and species of larger size are found in colder environments while species of smaller size are found in warmer regions. This rule was usually applied to large animals, mostly mammals and birds, but recently Sommer et al. (2017) reported that it holds also for marine phytoplankton. Maranon (2015) found that the biogeography of marine phytoplankton size structure is independent of temperature; however his analysis was, again, at the community level, and individual species were not addressed. Our study shows it is possible that the same principle, linking body size with the temperature of the environment, holds also for freshwater plankton, at least at the species level.

Although the results achieved in this study support our hypotheses based on the temperature-induced variations in water density and viscosity, further studies are needed to fully clarify how these factors finely modulate morphological variability in phytoplankton. Rasconi et al. (2015) also suggested that increasing water temperatures triggers dominance of small freshwater plankton. The convergence of the results achieved with the work by Rasconi et al. (2015), based on a different theoretical approach, shows that other temperature-dependent factors could be responsible for the morphological variability of phytoplankton. Our results further confirm, however, that if this phenomenon of larger cells or organisms of the same species at colder temperatures is widespread in lake phytoplankton, we would expect to see smaller-sized organisms in the future as global warming changes ambient temperatures.

\section{Acknowledgements}

The Israel Water Authority funded the monitoring program on Lake Kinneret, including the long-term monitoring of phytoplankton.

\section{Disclosure statement}

No potential conflict of interest was reported by the authors.

\section{References}

Acevedo-Trejos E, Brandt G, Bruggeman J, Merico A. 2015. Mechanisms shaping size structure and functional diversity of phytoplankton communities in the ocean. Sci Reports. 5:8918.

Adolph EF. 1931. The regulation of size as illustrated in unicellular organisms. Springfield (IL): Charles C. Thomas Publisher.

Bailey-Watts AE. 1986. Seasonal variation in size spectra of phytoplankton assemblages in Loch Leven, Scotland. Hydrobiologia. 138:25-42.

Bailey-Watts AE, Kirika A. 1981. The assessment of size variation in Loch Leven phytoplankton: a methodology and some of its uses in the study of factors influencing size. J Plankton Res. 3:261-282.

Bergmann C. 1847. Über die verhältnisse der wärmeökonomie der thiere zu ihrer grösse [On the relations of the thermal economy of animals to their size]. Göttinger Studien. 3:595708.

Bergquist AM, Carpenter SR, Latino JC. 1985. Shifts in phytoplankton size structure and community composition during grazing by contrasting zooplankton assemblages. Limnol Oceanogr. 30:1037-1045.

Berman T, Parparov A, Hadas O, Yacobi YZ, Sivan O, Ostrovsky I, Eckert W. 2014. The fate of organic carbon. In: Zohary T, Sukenik A, Berman T, Nishri A, editors. Lake Kinneret, ecology and management, aquatic ecology series 6. Dordrecht (Netherlands): Springer; p. 439-472.

Chisholm SW. 1992. Phytoplankton size. In: Falkowski PG, Woodhead AD, Vivirito K, editors. Primary productivity and biogeochemical cycles in the sea. Dordrecht (Netherland): Kluwer Academic; p. 213-237.

De Miranda M, Gaviano M, Serra E. 2005. Changes in the cell size of the diatom Cylindrotheca closterium in a hyperhaline pond. Chem Ecol. 21:77-81.

De Senerpont Domis LN, Elser JJ, Gsell AS, Huszar VLM, Ibelings BW, Jeppesen E, Kosten S, Mooij WM, Roland F, Sommer U, et al. 2013. Plankton dynamics under different climatic conditions in space and time. Freshwater Biol. 58:463-482.

Elliott JA, Jones ID, Thackeray SJ. 2006. Testing the sensitivity of phytoplankton communities to changes in water temperature and nutrient load, in a temperate lake. Hydrobiologia. 559:401-411.

Fanesi A, Wagner H, Becker A, Wilhelm C. 2016. Temperature affects the partitioning of absorbed light energy in freshwater phytoplankton. Freshwater Biol. 61:1365-1378.

Finkel ZE. 2007. Does phytoplankton cell size matter? The evolution of modern marine food webs. In: Paul G, Falkowski PG, Knoll AH, editors. Evolution of primary producers in the sea. London (UK): Academic Press; p. 333-350.

Hillebrand H, Dürselen CD, Kirschtel D, Pollingher U, Zohary T. 1999. Biovolume calculation for pelagic and benthic microalgae. J Phycol. 35:403-424.

Humphries SE, Imberger J. 1982. The influence of the internal structure and dynamics of Burrinjuck Reservoir on phytoplankton blooms. Environmental Dynamic Report ED 82-023. Nedlands (Western Australia): University Western Australia. 
Imberger I, Marti CL. 2014. The seasonal hydrodymanic habitat. In: Zohary T, Sukenik A, Berman T, Nishri A, editors. Lake Kinneret, ecology and management, aquatic ecology series 6. Dordrecht (Netherlands): Springer; p. 133-157.

Jung SW, Youn SJ, Shin HH, Yun SM, Ki JS, Lee JH. 2013. Effect of temperature on changes in size and morphology of the marine diatom, Ditylum brightwellii (West) Grunow (Bacillariophyceae). Estuar Coast Shelf Res. 135:128-136.

Kaplan-Levy RN, Alster-Gloukhovski A, Benyamini Y, Zohary T. 2016. Lake Kinneret phytoplankton: integrating classical and molecular taxonomy. Hydrobiologia. 764:283-302.

Lewis WM. 1976. Surface/volume ratio: implication for phytoplankton morphology. Science. 192:885-887.

Litchman E, Klausmeier CA. 2008. Trait-based community ecology of phytoplankton. Ann Rev Ecol Evol Syst. 39:615-639.

Lund JWG, Kipling C, Le Cren ED. 1958. The inverted microscope method of estimating algal numbers and the statistical basis of estimation by counting. Hydrobiologia. 11:143-170.

Maranon E. 2015. Cell size as a key determinant of phytoplankton metabolism and community structure. Ann Rev Mar Sci. 7:4.1-4.24.

Margalef R. 1978. Life forms of phytoplankton as survival alternatives in an unstable environment. Oceanol Acta. 1:493-509.

Naselli-Flores L. 2014. Morphological analysis of phytoplankton as a tool to assess ecological state of aquatic ecosystems: the case of Lake Arancio, Sicily, Italy. Inland Waters. 4:15-26.

Naselli-Flores L, Barone R. 2000. Phytoplankton dynamics and structure: a comparative analysis in natural and manmade water bodies of different trophic state. Hydrobiologia. 438:65-74.

Naselli-Flores L, Barone R. 2007. Pluriannual morphological variability of phytoplankton in a highly productive Mediterranean reservoir (Lake Arancio, Southwestern Sicily). Hydrobiologia. 578:87-95.

Naselli-Flores L, Barone R. 2011. Fight on plankton! Or, phytoplankton shape and size as adaptive tools to get ahead in the struggle for life. Cryptogamie Algol. 32:157-204.

Naselli-Flores L, Padisák J, Albay M. 2007. Shape and size in phytoplankton ecology: do they matter? Hydrobiologia. 578:157-161.

Padisák J, Soróczki-Pintér E, Rezner Z. 2003. Sinking properties of some phytoplankton shapes and the relation of form resistance to morphological diversity of plankton: an experimental study. Hydrobiologia. 500:243-257.

Paerl HW, Huisman J. 2008. Blooms like it hot. Science. 320:57-58.

Rasconi S, Gall A, Winter K, Kainz MJ. 2015. Increasing water temperature triggers dominance of small freshwater plankton. PLOS ONE. 10:e140449.

Reynolds CS. 1984. The ecology of freshwater phytoplankton. Cambridge (UK): Cambridge University Press.

Reynolds CS. 1997. Vegetation processes in the pelagic: a model for ecosystem theory. Oldendorf/Luhe: International Ecology Inst.

Reynolds CS. 2006. The ecology of phytoplankton. Cambridge (UK): Cambridge University Press.

Reynolds CS. 2012. Environmental requirements and habitat preferences of phytoplankton: chance and certainty in species selection. Bot Mar. 55:1-17.
Reynolds CS, Huszar VL, Kruk C, Naselli-Flores L, Melo S. 2002. Towards a functional classification of the freshwater phytoplankton. J Plankton Res. 24:417-428.

Reynolds O. 1883. An experimental investigation of the circumstances which determine whether the motion of water shall be direct or sinuous, and the law of resistance in parallel channels. T Roy Soc Lon. 174:935-982.

Rom M, Berger D, Teltsch B, Markel D. 2014. Material loads from the Jordan River. In: Zohary T, Sukenik A, Berman T, Nishri A, editors. Lake Kinneret, ecology and management, aquatic ecololgy series 6. Dordrecht (Netherlands): Springer; p. 309-327.

Salmaso N, Naselli-Flores L, Padisák J. 2015. Functional classifications and their application in phytoplankton ecology. Freshwater Biol. 60:603-619.

Smayda TJ. 1978. From phytoplankton to biomass. In: Sournia A, editor. Phytoplankton manual. Monographs on oceanographic methodology 6. Paris (France): UNESCO; p. 273-279.

Sommer U, Peter KH, Genitsaris S, Moustaka-Gouni M. 2017. Do marine phytoplankton follow Bergmann's rule sensu latu? Biol Rev. 92:1011-1026.

Sukenik A, Zohary T, Markel D. 2014. The monitoring programme. In: Zohary T, Sukenik A, Berman T, Nishri A, editors. Lake Kinneret, ecology and management, aquatic ecology series 6. Dordrecht (Netherlands): Springer; p. 561-575.

Thompson DW. 1917. On growth and form. Cambridge (UK): Cambridge University Press.

Utermöhl H. 1931. Neue Wege in der quantitativen Erfassung des Planktons [New approaches in quantifying the plankton]. Verh Int Verein Limnol. 5:567-595.

Vogel S. 1994. Life in moving fluids. the physical biology of flow. 2nd ed. Princeton (NJ): Princeton University Press.

Weithoff G, Gaedke U. 2017. Mean functional traits of lake phytoplankton reflect seasonal and inter-annual changes in nutrients, climate and herbivory. J Plankton Res. doi: 10.1093/plankt/fbw072

Yacobi YZ, Erez J, Hadas O. 2014. Primary production. In: Zohary T, Sukenik A, Berman T, Nishri A, editors. Lake Kinneret, ecology and management, aquatic ecology series 6. Dordrecht (Netherlands): Springer; p. 417-438.

Ziv B, Shilo E, Lechinsky Y, Rimmer A. 2014. Meteorology. In: Zohary T, Sukenik A, Berman T, Nishri A, editors. Lake Kinneret, ecology and management, aquatic ecology series 6. Dordrecht (Netherlands): Springer; p. 81-96.

Zohary T. 2004. Changes to the phytoplankton assemblage of Lake Kinneret after decades of a predictable, repetitive pattern. Freshwater Biol. 49:1355-1371.

Zohary T, Padisák J, Naselli-Flores L. 2010. Phytoplankton in the physical environment: beyond nutrients, at the end, there is some light. Hydrobiologia. 639:261-269.

Zohary T, Shneor M, Hambright KD. 2016. PlanktoMetrix a computerized system to support microscope counts and measurements of plankton. Inland Waters. 6:131-135.

Zohary T, Yacobi YZ, Alster A, Fishbein T, Lippman S, Tibor G. 2014. Phytoplankton. In: Zohary T, Sukenik A, Berman T, Nishri A, editors. Lake Kinneret, ecology and management, aquatic ecology series 6. Dordrecht (Netherlands): Springer; p. 161-190. 